\title{
Analisis Perilaku Konsumtif Dan Penanganannya
}

\author{
A. Nooriah Mujahidah \\ Bimbingan dan Kanseling, Fakultas Ilmu Pendidikan, Universitas Negeri Makassar. \\ Email: nocrymujahidah国gmail.com
}

\section{ABSTRACT}

This study discusses a student who is identified as carrying out consumptive behavior at Public SMK 8 Makassar. The main study of this research to find out: (1) Description of consumptive behavior in a student. (2) The factors that cause consumptive behavior in a student. (3) Self management techniques can reduce consumptive behavior in a student at Public SMK 8 Makassar. The approach to this research is qualitative with the type of case study research. Data analysis using descriptive analysis with triangulation techniques. The research result obtained: (1) Description of consumptive behavior in a student is often shop continuously, have a high interest in an item, inability to select the items needed, excessive shopping and tend to be difficult to manage finances properly. (2) The factors that cause consumptive behavior in a student is internal factors: motivation and external factors: lifestyle, advertisement, reference group, self-identification model and family. (3) Self Management Techniques are given to a student who performs consumptive behavior as a treatment that can reduce consumptive behavior in a student at Public SMK 8 Makassar.

Keywords: Consumptive Behavior, Self Management Techniques

\section{ABSTRAK}

Penelitian ini membahas tentang seorang peserta didik yang teridentifikasi melakukan perilaku konsumtif di SMK Negeri 8 Makassar. Kajian utama penelitian ini untuk mengetahui: (1) Gambaran perilaku konsumtif pada seorang peserta didik. (2) Faktor-faktor penyebab timbulnya perilaku konsumtif pada seorang peserta didik. (3) Teknik self management dapat mengurangi perilaku konsumtif pada seorang peserta didik. Pendekatan pada penelitian ini adalah kualitatif dengan jenis penelitian studi kasus. Analisis data menggunakan analisis deskriptif dengan teknik triangulasi. Hasil penelitian yang diperoleh: (1) Gambaran perilaku konsumtif pada seorang peserta didik yaitu sering berbelanja secara terus-menerus, memiliki ketertarikan yang tinggi terhadap suatu barang, ketidakmampuan menyeleksi barang yang dibutuhkan, belanja berlebihan, serta cenderung sulit mengatur keuangan dengan baik. (2) Faktor-faktor penyebab timbulnya perilaku konsumtif pada seorang peserta didik yakni faktor internal: motivasi serta faktor eksternal: gaya hidup, iklan, kelompok anutan/acuan, model identifikasi diri dan keluarga. (3) Teknik self management diberikan kepada seorang peserta 
didik yang melakukan perilaku konsumtif sebagai penanganan yang dapat mengurangi perilaku konsumtif pada seorang peserta didik di SMK Negeri 8 Makassar.

\section{Kata Kunci: Perilaku Konsumtif, Teknik Self Management}

(c) (1) () This is an open access article distributed under the Creative Commons Attribution License Cᄃ-BY-NC-4.0 四2021 by author (https://creativecommons.org/licenses/by-nc/4.D/).

(Received. Februari-2021; Reviewed: Maret-2021; Accepted: April-2021;

Available online. April-2021; Published: April-2021)

\section{PENDAHULUAN}

Manusia sebagai makhluk hidup di dunia ini memiliki banyak kebutuhan sehari-hari dalam hidupnya. Diantara kebutuhan tersebut terbagi atas kebutuhan primer, sekunder dan tersier. Hal tersebut senada dengan yang dikemukakan oleh Muh. Syarifuddin (2016: IOC-III) yang mengatakan bahwa kebutuhan manusia berdasarkan intensitasnya terdiri dari tiga macam meliputi kebutuhan primer, kebutuhan sekunder serta kebutuhan tersier. Dengan banyaknya kebutuhan manusia dalam kehidupannya sehari-hari, manusia tidak bisa lepas dalam melakukan kegiatan mengonsumsi yang dilakukan manusia dalam rangka memenuhi kebutuhan hidupnya sehari-hari.

Lestari (2018: 2) menyatakan bahwa individu selalu mencari kepuasan dengan mengonsumsi barang yang bukan kebutuhannya melainkan untuk memenuhi keinginannya. Fenomena ini biasanya dikenal dengan istilah perilaku konsumtif. Perilaku konsumtif merupakan perilaku dimana timbulnya keinginan untuk membeli barang-barang maupun menggunakan jasa hanya untuk memenuhi kepuasan pribadi semata dan tidak lagi memandang manfaat dari barang maupun jasa tersebut. Perilaku knnsumtif cenderung ditemui pada kalangan remaja. Dimana remaja melakukan perilaku konsumtif untuk memenuhi gaya hidup. Hal ini diperjelas oleh Loudan dan Bitta (Suminar. 2015: 146) yang mengemukakan bahwa remaja mudah terpengaruh dengan pola konsumsi yang berlebihan dan kuat untuk mengonsumsi suatu produk.

Perilaku konsumtif dapat terus mengakar dalam gaya hidup remaja dan dapat menimbulkan permasalahan dalam kehidupannya. Adapun dampak yang dapat dirasakan remaja dari segi ekonami yaitu ketika remaja terus melakukan perilaku kosumtif maka dia tidak lagi dapat mengatur keuangannya dengan baik. Sementara dampak yang dapat dirasakan remaja dari segi psikologis yaitu remaja akan mengalami tekanan jika keinginannya tidak dapat terpenuhi. Sementara dampak yang dapat dirasakan remaja dari segi sasial yaitu remaja akan terus mengikuti atribut yang banyak digemari tanpa mau manjadi diri sendiri (Effendi. 20I6).

Dari hasil studi pendahuluan yang dilakukan di SMK Negeri 8 Makassar, terdapat seorang peserta didik yang teridentifikasi melakukan perilaku konsumtif berinisial AP. AP ditetapkan melakukan perilaku knnsumtif karena berbelanja secara berlebihan, mudah tertarik ketika melihat suatu barang, tidak memerhatikan manfaat dari suatu barang, belanja terus-menerus serta cenderung borus. Sehingga AP menjadikan belanja sebagai pemenuhan gaya hidupnya. Hal inilah yang menyebabkan timbulnya perilaku knnsumtif pada AP, dimana dia tidak dapat mengontral dirinya untuk tidak berbelanja. Sementara AP tidak sadar bahwa perilaku konsumtif justru memiliki banyak dampak negatif. AP melakukan perilaku knnsumtif disebabkan karena ketidakmampuan mengelola hasrat dan godaan untuk belanja. Hal ini disebabkan AP cenderung tidak bisa mengontrol dirinya karena ketidakmampuannya dalam memanajemen diri dengan baik. Untuk itulah, AP perlu diberikan penanganan untuk mengurangi bahkan menghentikan perilaku konsumtifnya. Salah satu cara yang dapat dilakukan yaitu mengontrol diri dengan manajemen diri yang baik. Adapun teknik konseling yang tepat digunakan untuk mengurangi perilaku konsumtif yaitu dengan menggunakan teknik self management Hal ini berdasar pada hasil penelitian yang dilakukan oleh Anike Dian Fitri (2013) yang menyimpulkan bahwa strategi self management dapat mengurangi perilaku konsumtif pada siswa kelas X-II di SMAN I5 Surabaya. 

terhadap stimulus, tapi suatu tindakan yang disengaja (aperant). Tingkah laku terjadi ketika ada stimulus khusus. Self managementmerupakan suatu teknik yang mengarah kepada perilaku konseli, untuk membantu konseli dalam mengatur dan merubah perilaku ke arah yang lebih efektif melalui proses belajar tingkah laku baru (Corey. 2009).

Teknik self managementini dianggap tepat untuk mengurangi perilaku konsumtif konseli. Sebab masalah utama pada manusia yang melakukan perilaku konsumtif yaitu manusia tidak dapat mengantrol diri mereka karena ketidakmampuan mereka dalam memanajemen diri dengan baik. Untuk itulah, peneliti membahas penelitian yang berjudul "Analisis Perilaku Konsumtif dan Penanganannya (Studi Kasus pada Satu Peserta Didik di SMK Negeri 8 Makassar)".

Mengacu pada penjelasan di atas, maka tujuan yang ingin dicapai dalam penelitian ini yaitu untuk mengetahui:

I. Gambaran perilaku konsumtif pada subjek AP di SMK Negeri 8 Makassar.

2. Faktor yang menyebabkan perilaku konsumtif pada subjek AP di SMK Negeri 8 Makassar.

3. Keberhasilan teknik self management dalam mengurangi perilaku knnsumtif pada subjek AP di SMK Negeri 8 Makassar.

\section{METODE}

Pendekatan yang digunakan dalam penelitian ini yaitu pendekatan kualitatif. Sugiyono (2016: 14) mengatakan bahwa metode penelitian kualitatif sering disebut metade penelitian naturalistik karena penelitiannya dilakukan pada kandisi alamiah (natura/ setting).

Jenis penelitian yang digunakan dalam penelitian ini yaitu studi kasus. Menurut Yin (2015: I) studi kasus adalah salah satu metade peneilitan bidang ilmu sasial. Studi kasus digunakan untuk mengetahui tentang suatu permasalahan atau fenomena yang diteliti secara lebih mendalam dan terperinci (Tohirin. 2016: 20).

Berdasarkan penjelasan tersebut, maka peneliti menggunakan jenis penelitian studi kasus terhadap searang peserta didik yang teridentifikasi melakukan perilaku knnsumtif di SMK Negeri 8 Makassar. Penelitian ini dilakukan secara mendalam dan terperinci untuk menemukan gambaran-gambaran serta faktor penyebab perilaku knnsumtif untuk kemudian dapat dilakukan perencanaan penaganan dengan melaksanakan atau memberikan layanan bimbingan konseling yang tepat untuk menangani perilaku konsumtif.

\section{A. Kehadiran Peneliti}

Dalam penelitian ini, peneliti bertindak sebagai instumen kunci serta aktif dan pengumpul data dalam upaya mengumpulkan data-data di lapangan.

B. Subjek Penelitian

Subjek dalam penelitian ini merupakan searang peserta didik di SMK Negeri 8 Makassar pada kelas XI Boga 3 yang berinisial AP. Searang perempuan berusia I6 tahun yang berasal dari keluarga dengan status menengah. AP anak pertama dari dua bersaudara. AP ditetapkan sebagai subjek penelitian karena berdasarkan studi pendahuluan AP teridentifikasi melakukan perilaku konsumtif. Hal ini karena AP berbelanja secara berlebihan, mudah tertarik ketika melihat suatu barang, tidak memerhatikan manfaat dari suatu barang, belanja terus -menerus serta cenderung boros. Sehingga AP menjadikan belanja sebagai pemenuhan gaya hidupnya. Selain itu, AP juga mudah tertarik ketika melihat barang yang dimiliki oleh keluarga atau sahabatnya serta senang membeli barang yang dipromosikan atau digunakan oleh idolanya. AP juga berbelanja ketika melihat suatu barang yang bagus.

ᄃ. Lokasi Penelitian

Penelitian ini dilakukan di SMK Negeri 8 Makassar. Pemilihan lokasi penelitian karena berdasarkan studi pendahuluan yang dilakukan peneliti terdapat seorang peserta didik yang teridentifikasi melakukan perilaku konsumtif.

D. Jenis Data 


\section{Data Primer}

Peneliti menggunakan data primer untuk mendapatkan informasi mengenai perilaku konsumtif, yaitu dengan wawancara terhadap peserta didik berinisial AP.

\section{Data Sekunder}

Peneliti menggunakan data sekunder berupa catatan-catatan sebagai penunjang berlangsungnya penelitian yang diperaleh dari orang tua, sahabat/teman dekat, serta guru BK konseli, yang diharapkan dapat memberikan informasi akurat untuk memperkuat dan melengkapi informasi yang telah dikumpulkan sebelumnya pada data primer.

E. Tahap-Tahap Penelitian

I. Tahap sebelum ke lapangan, meliputi kegiatan penentuan fokus, penyesuaian dan paradigma dengan teori, penjajakan alat peneliti, mencakup observasi ke lapangan dan permohonan izin kepada subjek yang diteliti, konsultasi fokus penelitian, penyusunan sesudah penelitian.

2. Tahap pekerjaan lapangan, meliputi mengumpulkan bahan-bahan yang berkaitan dengan peserta didik yang melakukan perilaku konsumtif. Data diperoleh melalui wawancara, observasi dan dokumentasi.

3. Tahap analisis data, meliputi penafsiran data sesuai dengan konteks permasalahan yang diteliti, selanjutnya dilakukan pengecekan keabsahan dengan mengecek sumber data yang diperoleh dan metade perolehan data sehingga valid sebagai dasar dan bahan untuk memberikan makna data yang merupakan proses penentuan dalam memahami konteks penelitian yang sedang diteliti.

4. Tahap penulisan laparan, meliputi kegiatan penyusunan hasil penelitian dari semua rangkaian pengumpulan data sampai pemberian makna data.

F. Teknik Pengumpulan Data

I. Wawancara

Wawancara dilakukan bersama AP, selain itu peneliti juga melakukan wawancara bersama orang tua AP, sahabat/teman dekat AP dan guru BK AP. Peneliti menggunakan pedoman wawancara. Wawancara dilakukan untuk mendapatkan informasi tentang peserta didik yang teridentifikasi melakukan perilaku knnsumtif meliputi gambaran perilaku knnsumtif (terdiri atas intensitas belanja, ketertarikan terhadap godaan, ketidakmampuan menyeleksi barang yang dibutuhkan, kecenderungan belanja berlebihan serta pengaturan keuangan dan belanja) dan faktar-faktor penyebab timbulnya perilaku knnsumtif (terdiri atas faktor motivasi, faktor gaya hidup, faktor iklan, faktor kelompok anutan atau acuan, faktor model identifikasi diri serta faktor keluarga).

Wawancara dilakukan di rumah masing-masing dengan cara video call via WhatsApp. Hal ini dilakukan karena peneliti tidak bisa bertemu secara langsung dengan konseli dan informan lainnya untuk melakukan wawancara, disebabkan adanya pandemi Covid-19. Sebelum melakukan wawancara, terlebih dahulu peneliti menghubungi kanseli dan informan lainnya melalui chat via WhatsApp guna menyepakati waktu bersama untuk melakukan wawancara.

2. Dbservasi

Selain wawancara, peneliti mengumpulkan data melalui abservasi. Menurut Nurkancana (Harum \& Ibrahim. 2017: 64), menyatakan bahwa observasi adalah teknik pengumpulan data yang dilakukan melalui pengamatan secara langsung terhadap abjek penelitian dalam waktu tertentu dimana hal-hal yang ditemui dan didapatkan selama pengamatan kemudian dicatat secara sistematis.

Dalam penelitian ini, observasi dilakukan untuk menganalisis perilaku konsumtif pada peserta didik berinisial AP di SMK Negeri 8 Makassar. Aspek-aspek yang diobservasi mengenai perilaku konsumtif ini yaitu gambaran perilaku konsumtif yang meliputi intensitas belanja, ketertarikan terhadap godaan, ketidakmampuan menyeleksi barang yang dibutuhkan, kecenderungan belanja berlebihan serta pengaturan keuangan dan belanja. Selain itu, peneliti juga mengobservasi faktor-faktor penyebab timbulnya perilaku konsumtif pada AP yang meliputif faktor motivasi, faktor gaya hidup, faktor iklan, faktor kelompok anutan atau acuan, faktor model identifikasi diri serta faktor keluarga. 
Selain menganalisis perilaku knnsumtif pada AP, observasi juga digunakan untuk mencatat reaksi-reaksi dan perubahan yang dialami oleh AP selama mengikuti pelaksanaan konseling dengan menggunakan teknik self management, meliputi partisipasi subjek, semangat serta keseriusan mengikuti setiap tahap dalam kegiatan dan pemahaman mengenai teknik yang diberikan.

3. Dokumentasi

Beberapa dokumentasi yang akan digunakan dalam penelitian ini adalah catatan-catatan yang dibuat oleh subjek.

G. Teknik Analisis Data

1. Data Reduction (Reduksi Data)

Mereduksi data berarti merangkum, memilih hal-hal pokak, memfokuskan pada hal-hal penting, mencari tema dan polanya serta membuang yang tidak perlu.

2. Data Display (Penyajian Data)

Penyajian data atau mendisplaykan data bertujuan untuk memudahkan memahami yang terjadi, merencanakan kerja selanjutnya berdasarkan yang telah dipahami.

3. Kesimpulan

Kesimpulan awal yang dikemukakan masih bersifat sementara dan bisa berubah bila tidak ditemukan bukti-bukti yang kuat yang mendukung pada tahap pengumpulan data berikutnya. Namun apabila kesimpulan yang dikemukakan pada tahap awal, didukung oleh bukti-bukti yang valid dan konsisten saat peneliti kembali ke lapangan mengumpulkan data, maka kesimpulan yang dikemukakan merupakan kesimpulan yang kredibel.

H. Pemeriksaan Keabsahan Data

l. Triangulasi

Dalam penelitian ini triangulasi yang digunakan yaitu triangulasi sumber dan triangulasi metode/teknik.

\section{Member Lheck}

Apabila data yang ditemukan disepakati oleh subyek berarti data tersebut valid, sehingga semakin kredibel tetapi apabila data yang ditemukan peneliti tidak disepakati oleh subjek, maka penelitipun melalukan diskusi dengan subjek dan apabila perbedaannya tajam, maka peneliti harus mengubah temuannya dan harus menyesuaikan dengan yang diberikan oleh subjek.

\section{HASIL DAN PWMBAHASAN}

A. Hasil

1. Perilaku Konsumtif Subjek AP

a. Intensitas belanja

Perilaku yang di tampilkan: Berbelanja atau menggunakan jasa sekitar 6-7x dalam satu bulan yang dilakukan secara langsung maupun anline; Berbelanja makanan melalui layanan grab food sekitar 7-8x dalam satu bulan.

b. Ketertarikan terhadap gudaan (sugestibilitas terhadap gadaan)

Perilaku yang di tampilkan: Mudah tergoda barang diskon dan promo; Suka mengoleksi barang lucu, unik dan menarik.

c. Ketidakmampuan menyeleksi barang yang dibutuhkan

Perilaku yang di tampilkan: Tidak memikirkan manfaat barang yang dibeli untuk diri sendiri; Tidak bisa membedakan antara kebutuhan dan keinginan.

d. Kecenderungan belanja berlebihan

Perilaku yang di tampilkan: Belanja tidak terkontrol; Belanja berlebihan dengan membeli paling banyak tiga sampai empat barang sekaligus; Tetap membeli barang walaupun sudah memilikinya.

e. Pengaturan keuangan dan belanja 
Perilaku yang di tampilkan: Cenderung boras; Tidak bisa mengelola keuangan dan mengontrol diri dengan baik; Uangnya digunakan hanya untuk berbelanja barang keinginan.

2. Faktar Penyebab Timbulnya Perilaku Konsumtif pada Subjek AP

a. Faktar internal

1) Mativasi

Perilaku yang di tampilkan: Mengumpulkan beberapa barang untuk dikaleksi; Ingin menaikkan status sosial.

b. Faktor Eksternal

2) Gaya hidup

Perilaku yang di tampilkan: Berbelanja untuk memenuhi gaya hidup; Mengikuti trend/mode yang sedang banyak digunakan; Tidak ingin ketinggalan zaman.

3) $\quad \mid k l a n$

Perilaku yang di tampilkan: Tidak terlalu terpengaruh oleh iklan yang mempromosikan produk/barang; Lebih suka melihat barang secara langsung atau melihat gambar secara online.

4) Kelompok anutan atau acuan

Perilaku yang di tampilkan: Mudah terpengaruh oleh sahabat ketika diajak berbelanja; Senang diajak berbelanja oleh sahabat: Membeli barang sama seperti yang dimiliki aleh sahabat.

5) Model identifikasi diri

Perilaku yang di tampilkan: Mengidentifikasikan diri atau mengikuti yang digunakan aleh idala; Mudah terpengaruh oleh artis idola ketika membeli barang/produk.

6) Keluarga

Perilaku yang di tampilkan: Berbelanja dipengaruhi aleh keluarganya yaitu saudara yang juga sering berbelanja; Membeli barang yang dilihat/dimiliki oleh saudara; Ketika meminta uang atau sesuatu langsung diberikan oleh kedua orang tuanya; Meminta uang jajan lebih sehingga membuat ibunya mengeluh dan merasa resah karena belanja berlebihan.

3. Penanganan Perilaku Konsumtif Menggunakan Teknik Self Management

a. Tahap self-monitoring. Pada tahap ini konseli setuju mengikuti proses konseling dengan serius.

b. Tahap self-cuntracting. Pada tahap ini konseli aktif membahas dan cermat menentukan perencanaan/ strategi yang akan digunakan untuk mengurangi perilaku konsumtif.

c. Tahap s timulus control. Pada tahap ini knnseli serius mendengarkan contoh pelaksanaan perencanaan/ strategi mengurangi perilaku konsumtif yang telah ditentukan sendiri untuk dilaksanakan dalam keseharian konseli.

d. Tahap self-evaluation. Pada tahap ini konseli aktif menceritakan hambatan yang ditemui selama melaksanakan perencanaan/ strategi mengurangi perilaku dan aktif mengevaluasi perencanaan/ strategi mengurangi perilaku knnsumtif.

Tahap self-reward(reinforcementpositive): Pada tahap ini konseli antusias memberikan self-rewardberupa hadiah untuk diri sendiri setelah berhasil mengurangi perilaku konsumtif dan konseli merasa senang mendapatkan reinforcement pasitive berupa celengan dari peneliti.

B. Pembahasan

1. Gambaran Perilaku Konsumtif

Berdasarkan hasil penelitian yang diperoleh sesuai dengan penjelasan perilaku knnsumtif yang dikemukakan oleh Anggasari (Fitri. 2013: 30) yang menjelaskan perilaku konsumtif merupakan kegiatan membeli barang secara berlebihan sehingga barang-barang yang tidak diperlukan atau tidak penting juga ikut dibeli. Sependapat dengan penjelasan tersebut, Usman Effendi (20I6: 17) mengemukakan konsumtif merupakan perilaku konsumsi yang boros dan berlebihan, yang lebih mendahulukan keinginan di bandingkan kebutuhan, serta tidak ada skala prioritas atau dapat diartikan sebagai gaya hidup yang mewah. 
Berdasarkan hasil penelitian yang dilakukan, peneliti mengambil kesimpulan bahwa AP melakukan perilaku konsumtif. Hal ini disebabkan AP berbelanja secara terus-menerus, memiliki ketertarikan yang tinggi terhadap suatu barang, tidak mampu menyeleksi barang yang dibutuhkan, belanja berlebihan serta cenderung sulit mengatur keuangan dengan baik.

Hasil penelitian tersebut didukung oleh penjelasan Anggreini g Mariyanti (2014: 37-38) mengemukakan individu yang membeli suatu barang tanpa mempertimbangkan prioritas cenderung akan melakukan perilaku konsumtif seperti membeli barang karena melihat merek, membeli barang yang tidak sesuai dengan kebutuhan, membeli barang untuk menjaga penampilan dan gengsi, membeli karena adanya potongan harga, membeli karena adanya bonus, serta membeli barang karena bentuk yang menarik dan warna yang disukai.

\section{Faktor Penyebab Timbulnya Perilaku Konsumtif}

Berdasarkan hasil penelitian yang dilakukan, peneliti mengambil kesimpulan bahwa penyebab timbulnya perilaku konsumtif pada AP terdiri dari faktor internal dan faktor eksternal. Faktor internal meliputi: a) Faktor motivasi, menurut Chrisnawati dan Abdullah (Karmila. 2019: 12) menjelaskan motivasi yaitu suatu kekuatan yang digunakan individu dalam memunculkan dan mengarahkan tingkah lakunya. Hasil penelitian yang dilakukan diperoleh bahwa motif AP dalam berbelanja karena terdarang ingin mengumpulkan beberapa barang untuk dijadikan koleksi dan untuk bisa menaikkan status sasial. Hasil penelitian tersebut didukung oleh penjelasan Reinhart (Adzkiya. 2018: I6) mengemukakan bahwa kegiatan mengonsumsi dilakukan seseorang sebagai pemuas keinginan untuk bisa mencapai status tertentu melalui barang atau kegiatan yang bukan merupakan bagian dari kebutuhan diri.

Faktor eksternal meliputi: b) Faktor gaya hidup, menurut Raharjo dan Silalahi (Adzkiya. 2018: 16-17) menjelaskan gaya hidup merupakan pola hidup individu. Hasil penelitian yang dilakukan diperoleh bahwa AP berbelanja untuk pemenuhan gaya hidup dengan mengikuti trend/mode yang sedang banyak digunakan agar tidak ketinggalan zaman. Hasil penelitian tersebut didukung oleh penjelasan Estetika (2017: 9-10) mengemukakan bahwa gaya hidup merupakan penyebab perilaku konsumtif dimana seseorang dalam membeli barang selalu mengikuti perkembangan zaman; c) Faktor kelompok anutan atau acuan, menurut Hyman dan Singer (Effendi. 20IG: 86) menjelaskan dalam arti sempit kelompok anutan atau acuan yaitu mencakup kelompok-kelompok atau teman individu dalam melakukan interaksi secara langsung. Hasil penelitian yang dilakukan diperoleh bahwa AP ketika berbelanja mudah terpengaruh oleh sahabatnya selain itu juga AP merasa senang jika diajak berbelanja oleh sahabatnya. AP juga biasanya membeli barang yang sama seperti yang dimiliki oleh sahabat. Hasil penelitian tersebut didukung oleh penjelasan Sumartono (Karmila. 2019) mengemukakan bahwa sesearang melakukan perilaku konsumtif karena mengacu dengan yang ditentukan oleh kelompok referensinya; d) Faktor model identifikasi diri. Hasil penelitian yang dilakukan diperoleh bahwa AP dalam berbelanja mengidentifikasikan diri atau mengikuti yang digunakan oleh idolanya sehingga AP mudah terpengaruh oleh artis idolanya ketika membeli barang/produk. Hasil penelitian tersebut didukung oleh penjelasan Sumartono (Adzkiya. 2018: 13) mengemukakan memakai produk karena unsur kanformitas terhadap model yang mengiklankan, dimana tujuan membeli suatu produk karena mengidolakan model yang mengiklankan produk tersebut; e) Faktor keluarga, menurut Kartono (Karmila. 2019: 14) menjelaskan keluarga merupakan unit sosial terkecil yang dapat berfungsi sebagai contoh utama bagi perkembangan remaja. Hasil penelitian yang dilakukan diperoleh bahwa AP dalam berbelanja dipengaruhi oleh keluarganya yaitu saudaranya dimana adik AP juga sering berbelanja sehingga AP biasa ikut membeli barang yang dilihat/dimiliki oleh adiknya. AP cenderung dimanjakan oleh kedua orang tuanya dimana jika AP meminta uang atau menginginkan sesuatu maka kedua orang tuanya langsung memberikannya kepada AP. Selain itu, AP sering meminta uang jajan lebih dari jatah uang jajannya ketika ingin berbelanja. Sehingga hal ini membuat orang tua AP terutama ibunya mengeluh dan merasa resah karena AP belanja berlebihan. Hasil penelitian tersebut didukung oleh penjelasan Effendi (20I6: IOC) mengemukakan bahwa keluarga memiliki peranan penting di dalam studi perilaku knnsumen karena keluarga merupakan unit yang memakai dan membeli produk konsumen selain itu keluarga merupakan pengaruh utama pada perilaku dan sikap individu. 
Sehingga keluarga memegang peranan dalam pemutusan pembelian dimana jika pembelian dilakukan secara berlebihan maka akan mengakibatkan timbul perilaku knnsumtif pada salah satu anggata keluarga.

Berdasarkan hasil penelitian yang dilakukan terhadap AP menunjukkan faktor penyebab timbulnya perilaku konsumtif pada AP meliputi faktor internal dan fakor eksternal. Faktor internal meliputi faktor motivasi; Faktor eksternal meliputi faktor gaya hidup, faktor kelompok anutan atau acuan, faktor model identifikasi diri dan faktor keluarga.

3. Upaya Penanganan Perilaku Konsumtif

Berdasarkan intervensi yang dilakukan menunjukkan hasil bahwa perilaku konsumtif pada AP berkurang dimana pada awalnya AP berbelanja secara berlebihan, mudah tertarik ketika melihat suatu barang, tidak memerhatikan manfaat dari suatu barang, belanja terus-menerus dan cenderung boros. Kemudian perilaku konsumtif mulai berkurang hal ini ditunjukkan dengan: AP berbelanja ketika sedang membutuhkan atau kehabisan suatu barang saja, artinya AP sudah mampu mengurangi intensitas belanjanya; AP mampu menahan diri untuk tidak berbelanja ketika melihat barang yang bagus, artinya AP sudah mampu menahan diri terhadap godaan; AP juga mampu menyeleksi barang kebutuhan dan barang keinginan, mengutamakan kebutuhan daripada keinginan, membeli barang keinginan bersamaan dengan barang yang dibutuhkan dan membeli hanya satu saja barang keinginan, memikirkan manfaat barang yang dibeli untuk diri sendiri. Artinya AP sudah mampu menyeleksi barang yang dibutuhkan; Selain itu AP mampu mengurangi jumlah barang yang dibeli ketika berbelanja, berbelanja sesuai jumlah kebutuhan saja. Artinya AP sudah mampu mengurangi belanja berlebihannya; AP juga mampu mengatur keuangan dan belanja dengan baik, mulai menabung uang yang dimiliki sehingga sudah memiliki tabungan, serta berbelanja hanya ketika butuh saja. Artinya AP sudah mampu mengatur keuangan dan belanjanya.

Setelah pemberian penaganan dengan knnseling menggunakan teknik self management, peneliti melakukan pemantauan sebagai upaya dalam mendampingi dan mengawasi perilaku konsumtif pada AP. Pemantauan dilakukan dengan peneliti berkomunikasi bersama AP melalui chat via WhatsApp, hal yang dilakukan peneliti dalam pemantauan ini yaitu peneliti menanyakan tentang aktivitas belanja AP setelah pemberian penanganan melalui konseling. Dimana setelah menerima penanganan melalui konseling, AP sudah berhenti melihat barang di online shop dan bisa menahan diri untuk tidak berbelanja barang keinginan. Selain itu, AP sudah mencatat dan membedakan barang kebutuhan dan barang keinginannya serta mengutamakan kebutuhan daripada keinginan. AP juga berbelanja ketika kehabisan suatu barang saja dan memikirkan manfaat dari suatu barang untuk dirinya. Selain itu, AP sudah bisa mengatur keuangan dengan baik dan sering menabung uang jajannya perhari yang diberikan oleh orang tuanya. Berdasarkan hal tersebut terlihat bahwa telah terjadi perubahan perilaku pada AP dimana AP sudah mengurangi perilaku konsumtifnya dan perilaku AP tetap konsisten dan semakin meningkat saat dan setelah mengikuti konseling dengan teknik self management untuk penanganan perilaku knnsumtif.

Berdasarkan hasil penelitian dan konseling yang dilakukan kepada AP dapat disimpulkan, bahwa teknik se/f management dapat membantu peserta didik mengurangi perilaku knnsumtif. Hal ini berarti penggunaan teknik self managementdapat mengurangi perilaku konsumtif.

\section{SIMPULAN DAN SARAN}

\section{A. Simpulan}

Berdasarkan hasil penelitian disimpulkan bahwa:

I. Gambaran perilaku knnsumtif yang ditunjukkan oleh AP meliputi berbelanja secara terus-menerus, memiliki ketertarikan yang tinggi terhadap suatu barang, tidak mampu menyeleksi barang yang dibutuhkan, belanja berlebihan, serta cenderung sulit mengatur keuangan dengan baik.

2. Faktor yang menyebabkan timbulnya perilaku konsumtif pada AP terdiri dari faktor internal dan faktor eksternal. Faktor internal meliputi faktor motivasi. Faktor eksternal meliputi faktor gaya hidup, faktor kelompok anutan atau acuan, faktor model identifikasi diri dan faktor keluarga. 

membantu konseli dalam mengatur dan mengubah tingkah lakunya ke arah yang lebih efektif melalui proses belajar tingkah laku baru. Dilaksanakan lima kali pertemuan di rumah masing-masing secara daring dengan videa call via whatsapp. dengan lima tahap yaitu self-monittring, self-contracting, stimulus control, self-evaluation dan self-reward (reinforcement pusitive). Setelah intervensi diberikan terjadi perubahan pada konseli yang telah berhasil mengurangi perilaku knnsumtifnya hal ini ditunjukkan dengan konseli: berbelanja ketika sedang membutuhkan atau kehabisan suatu barang saja, mampu menahan diri untuk tidak berbelanja ketika melihat barang yang bagus, mampu menyeleksi barang kebutuhan dan barang keinginan, mengutamakan kebutuhan daripada keinginan, membeli barang keinginan bersamaan dengan barang yang dibutuhkan dan membeli hanya satu saja barang keinginan, memikirkan manfaat barang yang dibeli untuk diri sendiri, mampu mengurangi jumlah barang yang dibeli ketika berbelanja, berbelanja sesuai jumlah kebutuhan saja, mampu mengatur keuangan dan belanja dengan baik, mulai menabung uang yang dimiliki sehingga sudah memiliki tabungan, serta berbelanja hanya ketika butuh saja.

B. Saran

Berdasarkan simpulan dari hasil penelitian dan mengamati situasi selama di lapangan, peneliti mengajukan beberapa saran antara lain:

I. Bagi konseli: diharapkan mengurangi belanja yang sering dilakukannya dan ketika berbelanja mengutamakan membeli kebutuhan daripada keinginan. Selain itu, konseli diharapkan lebih semangat dan tekun lagi dalam mengurangi perilaku konsumtif. Sehingga konseli tidak boras lagi dan bisa memiliki tabungan.

2. Bagi orang tua: diharapkan mengontrol aktivitas belanja anaknya. Dan tidak terlalu mengikuti kemauan anak ketika ingin berbelanja. Selain itu, juga diharapkan mengatur dan memberikan uang jajan kepada anak secukupnya saja.

Bagi guru BK/knnselor: dapat mempergunakan teknik selfmanagementsebagai layanan teknik untuk mengurangi perilaku knnsumtif. Teknik self management dapat juga dikembangkan menjadi penelitian tindakan konseling dengan menerapkannya pada permasalahan yang berbeda. Selain itu, guru BK/konselor juga diharapkan lebih memperhatikan masalah-masalah yang dialami oleh peserta didik di sekolah. Bukan hanya berfakus pada masalah belajar peserta didik di sekolah tapi juga bisa berfokus pada masalah pribadi, sasial serta karir peserta didik.

\section{DAFTAR RUJUKAN}

Adzkiya, A. 2018. Analisis Perilaku Konsumtif dan Faktar Pendarongnya (Studi Kasus Mahasiswa Universitas Islam Negeri Syarif Hidayatullah Jakarta Angkatan 2017. Skripsi. Jurusan Ekonami Syariah Fakultas Ekonomi dan Bisnis UIN Syarif Hidayatullah Jakarta.

Anggreini, R., \& Mariyanti, S. 2014. Hubungan antara Kontrol Diri dengan Perilaku Kansumtif Mahasiswi Universitas Esa Unggul. Jurnal Psikalogi. Vol. 12 (1): 34-42.

Corey, G. 2009. Theory and Practice of Caunseling and Psychatherapy. USA: Thomson Higher Education.

Effendi, U. 2016. Psikglogi Kansumen. Jakarta: Rajawali Pers.

Estetika, M. 20I7. Analisis Faktor-Faktor yang Mepengaruhi Perilaku Konsumtif Siswa Perempuan Kelas XII IPS. Skripsi. Program Studi Pendidikan Ekonomi FKIP Untan Pontianak.

Fitri, A.D. 20|3. Penerapan Strategi Pengelolaan Diri (Self-Management) untuk Mengurangi Perilaku Konsumtif pada Siswa Kelas X-II SMAN I5 Surabaya. UNESA Journa/Mahasiswa Bimbingan dan Kanseling. Vol. I (I): 26-36.

Harum, A., \& Ibrahim M. 2017. Asesmen Psikalogis Teknik Nan Tes. Makassar: Penerbit FIP-UNM Universitas Negeri Makassar.

Karmila, R. 20I9. Penerapan Teknik Tought Stopping untuk Mengurangi Kecenderungan Perilaku Konsumtif Siswa di SMA Negeri 9 Makassar. Skripsi. Psikologi Pendidikan dan Bimbingan Fakultas Ilmu Pendidikan Universitas Negeri Makassar. 
Indonesian Jaurnal of School Counseling: Theory, Application and Development

Volume I Nomar I Tahun 2021. Pages DI-ID

p-ISSN: 2775-1708 \& e-ISSN: 2775-555X

Homepage: https://ojs.unm.ac.id/ijosc

DDI: https://dai.org/10.26858/ijosc.vili.19316

Lestari, Q.D. 2018. Hubungan antara Konformitas dengan Kecenderungan Perilaku Konsumtif pada Siswa Sekolah X. Jurna/ Psikalogi Industri dan Drganisasi. Vol. 5 (I): 2.

Sugiyono. 2016. Metode Penelitian Pendidikan (Pendekatan Kuantitatif, Kualitatif dan REDD). Bandung: Penerbit Alfabeta.

Suminar, E. 2015. Konsep Diri, Konfarmitas dan Perilaku Konsumtif pada Remaja. Jurnal/Psikalogi Indanesia. Vol. 4 (2): 145152.

Syarifuddin, M. 2016. Analisis tentang Aktivitas Buruh Tani dalam Memenuhi Kebutuhan Pokok di Kelurahan Bukuan Kecamatan Palaran Kota Samarinda. edourna/ Sasiatri-Sasiologi. Vol. 4 (3): 98 -III.

Tohirin. 2016. Metade Penelitian Kualitatif Dalam Pendidikan dan Bimbingan Kanseling: Pendekatan Praktis untuk Peneliti Pemula dan Dilengkapi dengan Contah Transkrip Hasil Wawancara Serta Madel Penyajäan Data. Jakarta: Rajawali Pers.

Yin, R.K. 2015. Studi Kasus: Desain dan Metode. Jakarata: Rajawali Pers. 